\title{
Organic Farming and Sustainable Agriculture in Malaysia: Organic Farmers' Challenges towards Adoption
}

\author{
Neda Tiraieyari ${ }^{1}$, Azimi Hamzah ${ }^{1} \&$ Bahaman Abu Samah $^{1}$ \\ ${ }^{1}$ Institute for Social Science Studies, University Putra Malaysia, Malaysia \\ Correspondence: Neda Tiraieyari, Institute for Social Science Studies, University Putra Malaysia, Malaysia. Tel: \\ 63-8-946-1866. E-mail: ntiraie@yahoo.com
}

Received: September 5, 2013 Accepted: December 17, $2013 \quad$ Online Published: January 26, 2014

doi:10.5539/ass.v10n4p1 URL: http://dx.doi.org/10.5539/ass.v10n4p1

\begin{abstract}
Agriculture in Malaysia is characterised by high levels of fertiliser and manure applications and consequently environmental pollution. Sustainable agriculture and organic farming are being promoted by the government as a way of eliminating unsustainable agriculture. Despite the benefits that organic farming brings to farmers and environments, its adoption rate is still low among Malaysian farmers. A study of organic farmers in the Cameron Highlands was conducted to reveal the challenges that have been occurred with regard to adoption of the practice. The results indicate that organic farmers face challenges with regard to land tenure, certification processes, hiring foreign workers, marketing, training and extension services and governmental support. Issues and challenges were discussed. The paper concludes with some recommendations.
\end{abstract}

Keywords: organic farmers, organic farming, small-scale producers, sustainable agriculture, Malaysia

\section{Introduction}

Environmentalists, ecologists, agricultural professionals, and policy makers are examining why the massive usage of chemicals in agriculture has led to soil and water pollution, loss of biodiversity, the destruction of natural habitats and many other negative consequences (Sadati, Fami, Asadi, \& Sadati, 2010). Sustainable agriculture is at the heart of organic agriculture. Organic Farming (OF) is one of the agro-ecological approaches needed to grow enough food for the increasing population (Azadi et al., 2011). This approach minimizes external inputs such as chemical fertilizers, pesticides to produce non-toxic crops. Thus, it is less environmentally damaging and has much potential to produce more food, as a news release from the University of Michigan has explained. It is known to be an approach that aims to overcome some negative impacts of the Green Revolution on soil, water, landscape, and humans. According to (Partab, 2010) OF is an ecological agriculture that mostly depend on the management of ecosystems. This agricultural approach is not applicable just for developed countries but is also suitable for the developing world as well. In developing countries can contribute to socio-economic sustainability (Scherr \& McNeely, 2008; Willer, Yussefi, \& International Federation of Organic Agriculture Movements, 2004). For instance, it is claimed that OF can help rural development by contributing to tourism activities and generating employment and income to support local economies, especially in poorer countries (Hülsebusch, 2007; Scialabba, 2000).

While about 1 billion people in the developing countries are suffering from food, shortages and environmental degradation through unsustainable agriculture, yields in developing countries could increase by converting to $\mathrm{OF}$ (American Chemical Society, 2006). According to (Smolik, Dobbs, \& Rickerl, 1995), OF is more profitable than conventional farming in the long-term. Studies conducted by (Badgley et al., 2007) have shown that OF can produce almost the same yield of conventional farming in developing countries. (Badgley et al., 2007) examined a global dataset of 293 examples, in order to compare yields of organic versus conventional methods of farming. Results showed that in developing countries, organic farmers produce $80 \%$ more than conventional farmers. (Badgley et al., 2007), also reported that OF could produce enough food and fiber to sustain the current human population without more land being cultivated. Another study by the (American Chemical Society, 2006) on 286 farm projects in 57 countries showed that organic farming not only protected the environment but also the yields increased by an average of 79 percent. According to Ann (2007), "OF can yield up to two or three times as much food as conventional farming on the same amount of land" which invalidates the assumption that OF cannot produce enough food and fiber to feed the world. 
Scholars have argued much about the urgency of sustainable agriculture generally and OF in particular, with regard to agriculturally based countries such as Malaysia (Ahmad, 2001; Barrow, Weng, \& Masron, 2009). In this country, almost $90 \%$ of Malaysian farmers in the food sector are small-scale producers for uneconomic sized farms, with a high cost of production, inputs and yield are low, and with low quality of products (Tiraieyari \& Uli, 2011). The government's policy towards agriculture stresses increasing production to achieve food self-sufficiency. The Malaysian government has helped farmers with fertilizer subsidies to increase their production and improve their income (FAO, 2004). Therefore, the efforts for producing sufficient food and fiber for self-sufficiency have meant that Malaysia has adopted an intensive agricultural system and consequently has suffered environmental damage (Barrow et al., 2009). However, recently because of the growing awareness of the effects of unsustainable agriculture on their health and nature, the demand for organic products has risen among consumers considerably (Christopher, 2012). According to (Rezai, Mohamed, \& Shamsudin, 2011) the rapid socio-economic development and the increasing standard of life has changed consumers' perceptions and awareness of organic products. As a result, the market for organic products in Malaysia has been developing quickly from few years back. Nonetheless, the supply of locally produced organic products is not enough to satisfy the increasing demand. Consequently, Malaysia needs to import organic production from other countries, especially from Australia, the U.S., and New Zealand (Christopher, 2012). In fact, the government has more appreciated the value of the agricultural sector and its contribution to the economy of country. Sustainable agriculture practices have also been lunched in the country in order to transform the agricultural sector in a sustainable manner. In the Third National Agriculture Policy (NAP3), organic agriculture was identified as a niche market opportunity for Malaysian small-scale producers (Ahmad, 2001). Even though the national agricultural policies are along with the standard of sustainable agriculture, but the current agricultural practices differ in terms of sustainability (Murad, Mustapha, \& Siwar, 2008) and efforts made to promote OF in Malaysia have not generated acceptable results. A number of farmers have also been adopted sustainable agriculture in general and $\mathrm{OF}$ in particular practices are negligible. Malaysian farmers' challenges towards adoption of the programme may not be entirely clear for the policy makers. To our knowledge, few researchers have focused their study on unsustainable agriculture and the environmental damage caused by conventional farmers in Malaysia (Barrow, Chan, \& Masron, 2010; Barrow, Clifton, Chan, \& Tan, 2005; Barrow et al., 2009). In fact, little is known about organic farmers that adopted such practices in Malaysia. This study is designed to highlight the challenges of organic farmers in Malaysia.

\subsection{Organic Farming in Malaysia}

In Malaysia, OF has a relatively young history (Christopher, 2012). It was begun by the Center for Environment, Technology and Development (CETDEM) in 1986 in a one ha in Sungai Buloh. In the mid-1990s, the country started to import organic products. The consumers for organic products were mainly cancer patients. In 1995 a number of commercial OF vegetable growers included more than 500 families (Wai, 1995). Malaysian government plans included encouraging small-scale producers to invest in OF as approach to increase their income, protect the environment and promote the country's exports. The NAP3 identified organic agriculture as a market opportunity, mainly for vegetable and fruits growers (Gunnar, 2007). In the eighth Malaysia Plan (2001 to 2005), the government aimed at increase of organic production by 250 ha (Wai, 1995). Government included the providing of assistance to farmers up to US $\$ 1,300$ per ha in forms of infrastructure development. This also involved a certification scheme to cover the domestic market. Organic farming received government support through the establishment of national regulations for the Malaysian Organic Certification Program known as Sijil Organik Malaysia (SOM), which was launched in 2003 by the DOA to facilitate OF in Malaysia and to certify farms based on the requirements of the Malaysian standard MS1529:2001 (Kala et al., 2011). This standard, which is based on the Malaysian standard, sets the requirements for production to cover all stage of production. Moreover, the standard includes standards to control those hazards that affect the environment, food and workers' health and safety (Malaysia \& Bahagian Pertanian, 2007). The scheme is open for participation by all farmers who are engaged in the primary production of fresh organic food products. The DOA is responsible for the implementation of the organic scheme. A group of trained agricultural officers has been assigned to carry out field inspection to verify that the farm operations or practices are in accordance with the organic standards. In 2002, the Minister of Agriculture noted that support services such as extensions, research, and development would be devoted for developing organic agriculture in Malaysia. In the ninth Malaysia Plan (2006-2010), the government targeted the OF, which was said to be worth more than US\$ 200 million over 5 years. The Ministry of Agriculture planned to have 20,000 ha of (OF) by year 2010 and to increase local production by 4,000 ha per year.

In 2001, the DOA reported that there were only 27 organic farmers in the whole country with a total area of 131 
ha. Currently, there are several privet organic farms in Malaysia. In 2010, it was about 42 certified holders occupying 1130 ha of land under OF system focusing on vegetable production, fruits, animal husbandry and aquaculture. In 2013 the DOA reported that there was a total of 89 farms occupying 1633.89 ha of land under OF and that 49 farmers have valid certification while 40 farmers had expired certification. The majority of organic farmers were in the Pahang states of Malaysia. OF is mostly restricted to vegetable growing and very few fruits are grown organically. Most organic fruits import from Australia, New Zealand, China, Korea and Japan. Local organic vegetables have a higher price; usually three times more than 1 conventional products due to the labor-intensive approach (Ahmad, 2001).

\section{Method}

This survey was designed to highlight the challenges that certified organic farmers are facing with regard to adoption of these practices. We used focus group interviews as a data collecting strategy. Qualitative data was collected from small groups of farmers that were successful in adopting organic technologies and in marketing their organic products. Data for this study was collected using focus group discussion (FGD) with organic farmers. Farm visits were also used to get a better vision of the problem. Focus group discussion (FGD) was conducted in March 2013.

\subsection{Location of Study}

The study was conducted in the district of Cameron Highland. The main reason why this area was studied is that it has been the most important productive region in producing vegetables in the country. It is a mountainous region of peninsular Malaysia with a total land area of 71,218 ha and mild temperatures and 5500 ha of the total land are devoted to agriculture. Due to the favorable climate, this area becomes the main producer of vegetable in Malaysia. Vegetable occupy (50\%) of agricultural land, followed by tea plantation $(40 \%)$, flower $(7 \%)$ and fruits (2\%) (Aminuddin, Ghulam, Abdullah, Zulkefli, \& Salama, 2005). Currently there are 13 certified organic farmers in Cameron highland. We managed to get certified organic farmers through contact with director of organic farmers' association. The organic farmers' association is an independent small organization named the Cameron Organic Produce (COP) managed by representatives of the organization. The organization was established in 1996.

\subsection{Participant and Sampling Procedures}

We conducted three focus group discussions with one group of organic farmers $(n=6)$ from the Cameron Organic Produce (COP), one group of individual organic farmers $(n=4)$ and directors and managers of COP as rich source of information $(n=3)$. According to Stewart and Shamdasani (1990) there are no general rules for the best number of focus groups. They mentioned the rationale of working out the number of groups according to the homogeneity of the population, and the comfort of research application. Furthermore, they suggested that one focus group may well be enough. Regarding the size of focus group, Carey (1994) revealed that smaller groups were more manageable than bigger group. She states that the fewer people there are in the group, the greater the possibility that they will interact. In this study one of the researchers who involved in the project played the role of moderator. Millward (1995) suggests that the moderator should be directly involved in the project because they will be sensitive to the issues. The moderator explained the method and the purposed of research to the participants prior to commencing the interview. The use of tape recorder was also explained, and participants were informed that they can stop the interview/ discussion at any time they wish.

\section{Results}

The following outline presents our findings on famers' challenges towards adopting (OF) in Cameron Highland.

\subsection{Land Issue}

Farmers mentioned the land issue as their main challenge, especially for those who do not own the land, in order to start organic farming. The issue of Temporary Occupation Licenses (TOLs) was brought up in the Cameron highland in the early 1980s. Farmers are allowed to cultivate the land temporarily and the land is renewed annually by the government but the government as the owner can reclaim the land. Hence famers are not motivated to invest in land conservation when they never know how long they will be able stay on the land. Furthermore, farmers cannot get financial assistance or any kind of loan from the banks since the banks do not recognize TOL to give loans to the farmers. Farmers also reported delays in renewing their TOLs. The majority of small-scale producers in Cameron Highland are working on land which is held by the issue of Temporary Occupation Licenses (TOLs) by the government. Although the organic farmers we interviewed own the land and work on farms of less than 2 ha, these were mostly inherited from their parents. But due to land issue in Cameron Highland they cannot expand their farms and buy more land. 


\subsection{Labour Shortages}

Organic farmers in Cameron highland reported that labour shortages as the second most important challenge. Since their activities are done manually and organic technologies are mostly labour intensive, they have greater labour needs compare conventional farming methods. Due to the lack of local labour, organic farmers rely heavily on foreign labour to handle their work effectively. There is a great need for organic farmers in Cameron Highland to employ foreign workers, especially those from Bangladesh, Sri Lanka and Indonesia. In Malaysia, foreign workers in the agricultural sector must be directly employed by the government due to the immigration procedures and the need for working permits. The needs of foreign employees in the Malaysian agricultural sector cannot be denied. However, the recent government's policy has been to create more employment opportunities for locals and there has been a serious effort by the Malaysian government to reduce the country's dependence on foreign labor.

\subsection{Lack of Training and Extension Services}

The farmers reported a lack of extension services for organic farming in Cameron Highland. There is no training in OF provided by the DOA or other government agencies to the farmers. Not much extension work has been done on transferring OF to the farmers. As a result organic farmers must seek information through multiple channels such as their colleagues, members of farmers' association, internet and attending workshop. The farmers reported that extension workers have little technical knowledge of organic agriculture. In other words, extension workers are not specifically trained in organic agriculture.

\subsection{Marketing}

Farmers reported two main challenges in marketing their products in Malaysia. Firstly, the majority of people are not aware of the health benefits of consuming organic products, although demand for organic products has risen considerably among Malaysian people. Secondly, many people cannot afford to purchase organic products. Organic farmers have overcome these challenges partly by marketing their products through farmers' associations. The organic farmers' association establishes direct contact with special domestic buyers. The organic farmers' association in $\mathrm{CH}$ had also developed a specific website for selling their own products. Organic farmers also mentioned that exporting their products to a neighboring country such as Singapore is another challenge for them, although the demand for organic products in Singapore is very high. However, this country does not import organic products which are produced and certified to the SOM standard.

\subsection{Certification Process}

One of the main problems of the certification process is that it is extremely expensive. In addition, some unnecessary complexity increases confusion among farmers. Moreover, they reported the certification process takes too long for the government, at roughly 2-3 years. Organic farms have to be examined annually by a certified provider. Normally, members of the farmers' association build strong social relationship among themselves for developing and spreading information to overcome the complexity of the certification process.

\subsection{Governmental Support}

The farmers mentioned a lack of financial support from the government as their last but not their least challenge. In fact, organic farming requires significant on-farm and off-farm investment. Organic farmers need financial support to support their investments in soil conservation, production costs, labour costs, certification cost, and packing and storage facilities. According to the farmers, the government is not providing incentives for organic farmers. Mostly they receive help from NGOS.

\section{Discussion and Conclusion}

This article has reviewed the status of sustainable agriculture and organic farming in Malaysia. Sustainable practice has great potential in the country and therefore needs considerable support from the government. Maximizing production has been the most important goal for agricultural agencies and as a result governmental support for sustainable agriculture and organic farming has been limited. Organic farming and sustainable agriculture has not been practiced by the majority of farmers and the percentage of organic farmers in Malaysia is very small. Focusing on environmental awareness cannot secure conversion and it should not be the only approach offered by agricultural agencies to farmers. Government agencies should go beyond promoting such practices. The results of this study have also revealed challenges to organic farmers in Cameron Highland in terms of adoption of organic practices; include land issue, labour shortages, a lack of training and extension services and marketing, a lack of governmental support and the certification process. Among these the land issue appears to be the most serious barrier for farmers in converting to organic farming in Cameron Highland. Land tenure is critical to the adoption of such programmes. Obviously, tenant farmers would not be interested in 
investing in the land and go through a difficult conversion period without a strong guarantee of access to the land in later years. The unsolved land issue in Cameron Highland inhibits adoption of any sustainable agricultural practices. Organic agriculture is being promoted in Malaysia as a strategy to raise small-scale producers' income, protect the environment, and reduce food imports. However, from almost 2000 small-scale producers in Cameron Highlands who mainly work on farms of less than 2 ha only 13 adopted the program (Barrow, 2010). These 13 organic farmers own the land. One of the main ways Malaysian governments could influence adoption of the new method is through establishing property rights for small-scale producers. Wealthy farmers should not only be the target group for the program. Initially the DOA can begin with those who have stable forms of land tenure and can provide incentives and extension services to them. In addition, the Malaysian government should promote long-term rental contracts for small-scale producers and make provision to compensate farmers upon the termination of their contracts for investments made by them to improve the land. The Government should also target landowners and convince them of the importance of the land-conservation measures needed to obtain their support before promoting organic agriculture among small-scale producers.

It appears that small-scale producers rely on friends and media to receive information on organic farming. In order to promote the adoption of organic agriculture among small-scale producers, the government should support the adoption of the programme. The DOA should implement a policy of providing information on and research into organic farming. Agricultural extension has been essential in transforming the quality of information supplied to farmers. So the government should increase training for extension agents and specialists so that they can become recognized as useful sources of information on organic production. The DOA and other agricultural agencies should put organic farming on their priority programme list in order to facilitate the building of knowledge and human resources development. In other words, the success of this programme depends to a large extend on the training of farmers. The DOA should take steps to create adequate human resources and experts in research and extension should be one of its first priorities. An adequate number of well-trained extension agents on sustainable agriculture generally and OF specifically will play significant role in achieving sustainable agriculture in Malaysia. The DOA should facilitate the regular delivery of knowledge and experiences to farmers and provide them with direct incentives. Research, education, and extension efforts on sustainable agriculture and organic farming should be directed to organic agriculture in Malaysia.

The government can play a role in improving market access and helping organic farmers establish local marketing association. There are market opportunities for tropical countries such as Malaysia, especially for products that are not produced in Europe. Policy makers can also focus on the successful experiences of some Asian countries such as Japan, China, Korea and Thailand for Malaysia.

It is recommended that Malaysia needs to allocate resources and expertise to create organic research and development institutions/agencies. The government should consider providing direct incentives and some financial support to organic farmers. They should also facilitate certification process systems and hire foreign labour, in order for such projects to be successful.

\section{Acknowledgements}

We would like to thank the Research Management Center (RMC) in UPM, which supported this study.

\section{References}

Ahmad, F. (2001). Sustainable agriculture system in Malaysia. In Regional Workshop on Integrated Plant Nutrition System (IPNS), Development in Rural Poverty Alleviation, United Nations Conference Complex, Bangkok, Thailand (pp. 18-20). Retrieved from http://banktani.tripod.com/faridah.pdf

American Chemical Society. (2006). Sustainable Farm Practices Improve Third World Food Production. Science Daily. Retrieved from http://www.sciencedaily.com/releases/2006/01/060123163315.htm

Aminuddin, B. Y., Ghulam, M. H., Abdullah, W. Y. W., Zulkefli, M., \& Salama, R. B. (2005). Sustainability of Current Agricultural Practices Int. Cameron Highlands, Malaysia. Water, Air, \& Soil Pollution: Focus, 5, 89-101. http://dx.doi.org/10.1007/s11267-005-7405-y

Ann, A. (2007). Organic farming can feed the world, U-M study shows. School of Natural Resources and Environment, University of Michigan. Retrieved June 26, 2013, from http://www.snre.umich.edu/newsroom/2007-07-10/organic-farming-can-feed-the-world-u-m-study-shows

Azadi, H., Schoonbeek, S., Mahmoudi, H., Derudder, B., De Maeyer, P., \& Witlox, F. (2011). Organic agriculture and sustainable food production system: Main potentials. Agriculture, Ecosystems \& Environment, 144(1), 92-94. http://dx.doi.org/10.1016/j.agee.2011.08.001 
Badgley, C., Moghtader, J., Quintero, E., Zakem, E., Chappell, M. J., Avilés-Vázquez, K., \& Perfecto, I. (2007). Organic agriculture and the global food supply. Renewable Agriculture and Food Systems, 22(2), 86. http://dx.doi.org/10.1017/S1742170507001640

Barrow, C. J., Chan, N. W., \& Masron, T. B. (2010). Farming and Other Stakeholders in a Tropical Highland: Towards Less Environmentally Damaging and More Sustainable Practices. Journal of Sustainable Agriculture, 34, 365-388. http://dx.doi.org/10.1080/10440041003680205

Barrow, C. J., Clifton, J., Chan, N. W., \& Tan, Y. L. (2005). Sustainable development in the Cameron highlands, Malaysia. Malay. Journal of Environmental Management, 6, 41-57.

Barrow, C. J., Weng, C. N., \& Masron, T. (2009). Issues and challenges of sustainable agriculture in the Cameron Highlands. Malaysian Journal of Environmental Management, 10(2), 89-114. Retrieved from http://journalarticle.ukm.my/2290/

Carey, M. (1994). The group effect in focus groups: Planning, implementing, and interpreting focus group research. In J. Morse (Ed.), Critical Issues in Qualitative Research Methods (pp. 225-241). Sage Publications, London.

Christopher, T. B. S. (2012). Organic agriculture and food in Malaysia. Christopher Teh Boon Sung. Retrieved June 26, 2013, from http://christopherteh.com/blog/2012/02/organic-agriculture/

FAO. (2004). Fertilizer use by crop in Malaysia. Retrieved June 26, 2013, from http://www.fao.org/docrep/007/y5797e/y5797e00

Goh, C. S., Tan, K. T., Lee, K. T., \& Bhatia, S. (2010). Bio-ethanol from lignocellulose: Status, perspectives and challenges in Malaysia. Bio resource Technology, 101(13), 4834-4841. http://dx.doi.org/10.1016/j.biortech.2009.08.080

Hanim, A. (2011). Agriculture becoming major contributor to GDP. The Star Online Business. Retrieved July 3 , 2013 , from file://C:/Users/IPSAS-UPM/AppData/Roaming/Mozilla/Firefox/Profiles/dpu0nm1j.default/zotero/storage/ VGQ7FJ3T/Agriculture\%20becoming\%20major\%20contributor\%20to\%20GDP.htm

Hülsebusch, C. (2007). Organic Agriculture in the Tropics and Subtropics-Current Status and Perspectives. kassel university press $\mathrm{GmbH}$.

Kala, D. R., Rosenani, A. B., Fauziah, C. I., Ahmad, S. H., Radziah, O., \& Rosazlin, A. (2011). Commercial Organic Fertilizers and their Labeling in Malaysia. Management Journal of Soil Science, 15, 147-157. Retrieved from http://www.msss.com.my/mjss/Full\%20Text/Vol\%2015/kala.pdf

Kamaruddin, R., \& Masron, T. A. (2010). Sources of growth in the manufacturing sector in Malaysia: Evidence from ardl and structural decomposition analysis. Retrieved from http://www.academia.edu/download/30908574/AAMJ_15.1.6.pdf

Malaysia and Bahagian Pertanian. (2007). Standard Skim Organik Malaysia (SOM) Malaysian organic scheme. Putrajaya: Jabatan Pertanian Malaysia.

Millward, L. (1995). Focus groups. In G. Breakwell, S. Hammond, \& C. Fife-Schaw (Eds.), Research Methods in Psychology (pp. 274-292). Sage Publications, London.

Mohamed, M. S. (2007). Status and Perspectives on Good Agricultural Practices in Malaysia. Food and fertilizer technology center. $\quad$ Retrieved http://www.agnet.org/library.php?func=view\&id=20110725102453

Murad, M. W., Mustapha, N. H. N., \& Siwar, C. (2008). Review of Malaysian Agricultural Policies with Regards to Sustainability. American Journal of Environmental Sciences, 4(6), 608-614. http://dx.doi.org/10.3844/ajessp.2008.608.614

Partab, T. (2010). Merging organic farming sector in Asia: A synthesis of challenges and opportunities. In T. Partab, \& M. Saeed (Eds.), Organic Agriculture and Agribusiness: Innovation and Fundamentals. The Asian Productivity Organization. Retrieved from http://www.apo-tokyo.org/publications/files/agr-22-oaa.pdf

Rezai, G., Mohamed, Z., \& Shamsudin, M. N. (2011). Malaysian consumer's perceptive towards purchasing organically produce vegetable. In 2nd International Conference on Business and Economic Research, Holiday Villa Beach Resort and Spa, Langkawi, Kedah, Malaysia. Retrieved from http://www.internationalconference.com.my/proceeding/2ndicber2011_proceeding/310-2nd\%20ICBER\%20 
2011\%20PG\%201774-1783\%20Malaysian\%20Consumers\%20Perceptive.pdf

Sadati, A., Fami, H. S., Asadi, A., \& Sadati, A. (2010). Farmer's Attitude on Sustainable Agriculture and its Determinants: A Case Study in Behbahan County of Iran. Research Journal of Applied Sciences, Engineering and Technology, 2(5), 422-427.

Scherr, S. J., \& McNeely, J. A. (2008). Biodiversity conservation and agricultural sustainability: Towards a new paradigm of "eco agriculture" landscapes. Philosophical Transactions of the Royal Society Biological Sciences, 363(1491), 477-494. http://dx.doi.org/10.1098/rstb.2007.2165

Scialabba, N. (2000). Factors influencing organic agriculture policies with a focus on developing countries. In IFOAM 2000 Scientific Conference, Basel, Switzerland (pp. 28-31). Retrieved from http://www.fao.org/docs/eims/upload/230159/BaselSum-final.pdf

Smolik, J. D., Dobbs, T. L., \& Rickerl, D. H. (1995). The relative sustainability of alternative, conventional, and reduced-till farming systems. American Journal of Alternative Agriculture, 10(1), 25-35. http://dx.doi.org/10.1017/S0889189300006081

Stewart, D., \& Shamdasani, P. (1990). Focus groups Theory and Practice. Sage Publications, Beverly Hills, CA.

Tiraieyari, N., \& Uli, J. (2011). Sustainable Agriculture in Malaysia: Implication for Extension Workers. Journal of American Science, 7(8). Retrieved http://www.jofamericanscience.org/journals/am-sci/am0708/018_6034am0708_179_182.pdf

Wai, O. K. (1995). The role of agriculture and rural development in Malaysia. IV. National study: Malaysia IV. Retrieved July 4, 2013, from http://www.unescap.org/rural/doc/oa/Malaysia.PDF

Willer, H., Yussefi, M., \& International Federation of Organic Agriculture Movements. (2004). The world of organic agriculture: Statistics and emerging trends. Bonn, Germany: IFOAM.

\section{Copyrights}

Copyright for this article is retained by the author(s), with first publication rights granted to the journal.

This is an open-access article distributed under the terms and conditions of the Creative Commons Attribution license (http://creativecommons.org/licenses/by/3.0/). 